\title{
RICE HUSK DERIVED WASTE MATERIALS AS PARTIAL CEMENT REPLACEMENT IN LIGHTWEIGHT CONCRETE
}

\author{
Utilização de resíduos derivados da casca de arroz como \\ substitutos parciais do cimento no concreto leve
}

\author{
Celso Yoji Kawabata ${ }^{1}$, Holmer Savastano Junior², Joana Sousa-Coutinho
}

\begin{abstract}
In this study rice husk ash (RHA) and broiler bed ash from rice husk (BBA), two agricultural waste materials, have been assessed for use as partial cement replacement materials for application in lightweight concrete. Physical and chemical characteristics of RHA and BBA were first analyzed. Three similar types of lightweight concrete were produced, a control type in which the binder was just CEMI cement (CTL) and two other types with 10\% cement replacement with, respectively, RHA and BBA. All types of similar lightweight concrete were prepared to present the same workability by adjusting the amount of superplasticizer. Properties of concrete investigated were compressive and flexural strength at different ages, absorption by capillarity, resistivity and resistance to chloride ion penetration (CTH method) and accelerated carbonation. Test results obtained for $10 \%$ cement replacement level in lightweight concrete indicate that although the addition of BBA conducted to lower performance in terms of the degradation indicative tests, RHA led to the enhancement of mechanical properties, especially early strength and also fast ageing related results, further contributing to sustainable construction with energy saver lightweight concrete.
\end{abstract}

Index terms: Agricultural waste, rice husk ash, broiler bed ash, degradation.

\section{RESUMO}

Neste trabalho, cinzas de casca de arroz (RHA) e cinzas de cama de frango (BBA), dois resíduos agrícolas, foram avaliadas para uso como substitutos parciais do cimento para produção de concreto leve. Características físicas e químicas de RHA e BBA foram analisadas. Três tipos semelhantes de concreto leve foram produzidos, um controle em que o ligante era totalmente cimento CEM I (CTL) e dois outros tipos de concreto, com substituição de 10\% com RHA e BBA, respectivamente. Todos os tipos de concreto leve foram feitos através do ajuste da quantidade de superplastificante para apresentarem a mesma trabalhabilidade. Propriedades de concreto investigados foram resistência à compressão e à flexão em diferentes idades, a absorção por capilaridade, resistividade e resistência à penetração de íons cloreto (método CTH) e carbonatação acelerada. Os resultados dos testes obtidos para o nível de $10 \%$ de de substituição de cimento em concreto leve indicam que, embora a adição de BBA tenha conduzido a desempenho inferior em termos dos testes indicativos de degradação, a RHA levou à melhoria das propriedades mecânicas, especialmente resistência inicial e também resultados relacionados ao envelhecimento acelerado, contribuindo para a construção sustentável.

Termos para indexação: Resíduo agrícola, cinza de casca de arroz, cinza de cama de frango, degradação.

\section{(Received in april 19, 2012 and approved in june 19, 2012)}

\section{INTRODUCTION}

Experience all over the world, both historically and during the last several decades, shows that the Portland cement - pozzolanic/cementitious materials composite system will always be inherently superior to the Portland cement system in its microstructural and durability properties. This implies that there are strong technical and economic arguments and evidence to modify the fineness of the industrial (or agricultural) byproducts rather than that of the Portland cement, and thus ensure that they are manufactured for durability rather than for strength (SWAMY, 2008).
It is well known that rice husk ash, an agricultural waste material, can be a highly reactive pozzolanic material produced by controlled burning of rice husk and providing several advantages, such as improved strength and durability properties, reduced materials cost due to cement savings and environmental benefits (FAIRBAIRN et al., 2010). Reactivity of RHA is attributed to its high content of non-crystalline silica, and to its very large surface area governed by the cellular structure of the particles (SAFIUDDIN; WEST; SOUDKI, 2012; ZAIN et al., 2011).

Generally, reactivity of a pozzolanic material can be favored by increasing fineness (GANESAN; RAJAGOPAL;

\footnotetext{
'Universidade Federal do Maranhão/UFMA - Departamento de Produção Animal - MA-230 - Km 04 - s/n - Boa Vista - 65500-000 - Chapadinha MA - Brasil - celsoyk@yahoo.com

${ }^{2}$ Universidade de São Paulo/USP - Departamento de Engenharia de Alimentos - Pirassununga - SP - Brasi

${ }^{3}$ University of Porto - Civil Engineering Department - Porto - Portugal
}

Ciênc. agrotec., Lavras, v. 36, n. 5, p. 567-578, set./out., 2012 
THANGAVEL, 2007; CHINDAPRASIRT; RUKZON, 2008; CHAO-LUNG; ANH-TUAN; CHUN-TSUN, 2011). When burning temperature exceeds $600^{\circ} \mathrm{C}$ partially changing silica to cristobalite, quartz and trydimite (BOUZOUBAÂ; FOURNIER, 2001), this is, for crystalline material, grinding is especially important.

Lightweight aggregate presents the ability to absorb large quantities of water (important for selection of mix proportions and associated properties of resultant concrete) and also to allow a limited ingress of fresh cement paste into the open (surface) pores of the aggregate particles, specially the larger ones. Of particular importance is the fact that, according to Zhang and Gjorv, cited by Neville (1998), sealed-surface (coated) particles of good quality expanded clay aggregate have a $30 \mathrm{~min}$ absorption of just over one-half of the same material with the coating removed by cutting the particles. However some aggregates have a coating which is less effective. In general, for the same strength of concrete, the cement content is higher than in normal weight concrete (NEVILLE, 1998).

The main objective of this study was to evaluate the performance of the rice husk ash and the broiler bed ash as two potential residues for partial substitution of ordinary Portland cement in lightweight concrete. This work can open a new field of applications for the ashes coming from agroindustry wastes and related to the production of lightweight cement based materials.

\section{MATERIAL AND METHODS}

Control (CTL) lightweight concrete was produced with $100 \%$ Portland cement (CEM I). The remaining concrete types were produced with $10 \%$ replacement of the cement by rice husk ash and broiler bed ash, both produced in the laboratory. All concrete types with the same water/binder ratio were dosed with superplasticizer so as to present equivalent workability.

Properties analyzed for the lightweight concretes under evaluation were: specific gravity at 90 days; flexural strength at 3, 7, 28 and 90 days; compressive strength at 3, 7, 28 and 90 days; activity index at 28 and 90 days; resistivity at 63 days; resistance to chloride ion penetration at 63 days; absorption by capillarity at 63 days; and resistance to accelerated carbonation.

Cement: Cement used was of type CEM I 42.5 R in accordance with EN 197-1 (2001). SEM was carried out on a JSM-6301 F (Jeol) Scanning Microscope and pictures with the morphological aspect of the grains and the elemental analysis are shown in figure 1.

Rice husk ash: Rice husk was heated at a rate of $10^{\circ} \mathrm{C} \mathrm{m^{-1 }}$ and incinerated at $600^{\circ} \mathrm{C}$ for $03 \mathrm{~h} 00$ followed by natural cooling. It was then ground in a ball mill for about $10 \mathrm{~h} 00$.

Broiler bed ash: Broiler bed ash was obtained by incinerating broiler bed based on rice husk. The waste material was heated at a rate of $10^{\circ} \mathrm{C} \mathrm{min}{ }^{-1}$ and incinerated at $600^{\circ} \mathrm{C}$ for $03 \mathrm{~h} 00$ followed by natural cooling and then ground in a ball mill for about $10 \mathrm{~h} 00$.

Admixture, sand and lightweight aggregate: The superplasticizer used was Sika ViscoCrete 3000 an aqueous solution polycarboxylate based, presenting a specific gravity of $1.05 \mathrm{~kg} \mathrm{dm}^{-3}$ and $\mathrm{pH}$ around 5.0 .

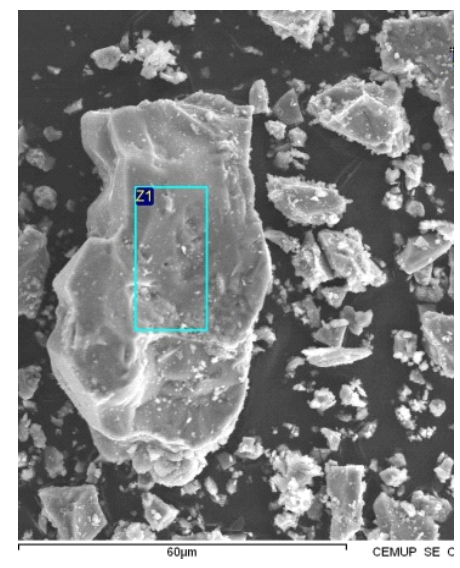

SEM image of cement particles, X 1500

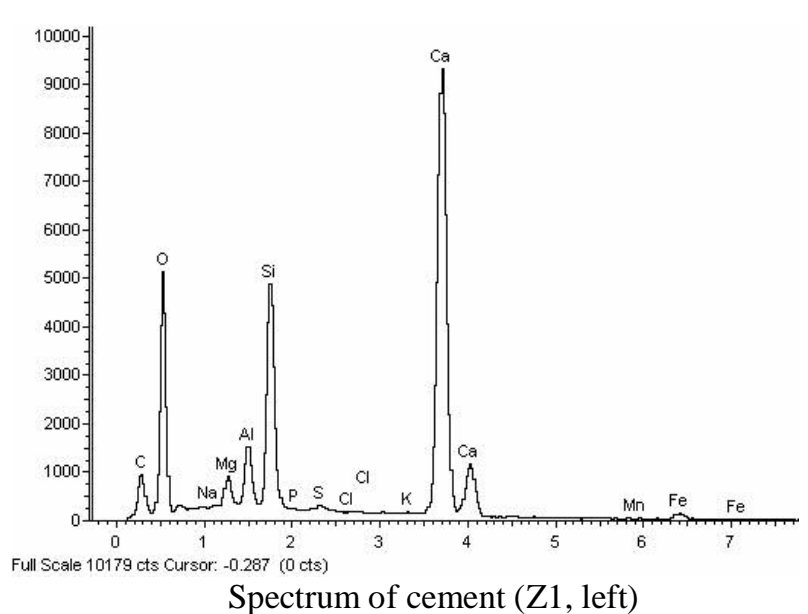

Spectrum of cement (Z1, left)

Figure 1 -SEM study of the particles morphology and elementary spectrum for the ordinary Portland cement CEM I $42.5 \mathrm{R}$.

Ciênc. agrotec., Lavras, v. 36, n. 5, p. 567-578, set./out., 2012 
Lightweight aggregate LECA 2/4 (Maxit) and a fine natural siliceous sand were used with particle size distributions shown in table 1.

Table 1 - Particle size distribution of sand and lightweight aggregate LECA 2/4.

\begin{tabular}{crr}
\hline \multirow{2}{*}{ Sieve aperture $(\mathrm{mm})$} & \multicolumn{2}{c}{ Passed \% } \\
\cline { 2 - 3 } & Leca $2 / 4$ & \multicolumn{1}{c}{ sand } \\
\hline 8 & 100.00 & 100.00 \\
5.6 & 100.00 & 99.51 \\
4 & 97.42 & 97.65 \\
2 & 8.48 & 92.26 \\
1 & 1.60 & 84.22 \\
0.5 & 1.19 & 59.91 \\
0.25 & 1.03 & 13.36 \\
0.125 & 0.87 & 1.11 \\
0.063 & 0.59 & 0.62 \\
$<0.063$ & 0.31 & 0.00 \\
\hline
\end{tabular}

Concrete production: Ash obtained from waste materials, rice husk ash and broiler bed ash, was considered as partial replacement for Portland cement. Three types of lightweight concrete presenting equivalent workability were produced (Table 2), control concrete (CTL) with 100\% of Portland cement (CEM I, class 42.5R), a second type with $10 \%$ cement replacement with rice husk ash (RHA) and a third type with $10 \%$ replacement of broiler bed ash (BBA). The replacement percentage of $10 \%$ was considered based on the research carried out by other authors (CHANDRA; CHAO, 1997; GANESAN; RAJAGOPAL; THANGAVEL, 2008). The ratio "binder:lightweightaggregate:sand:water" for all types of concrete was 1/0.814/ $1.389 / 0.38$ by weight.
After assessing workability, several prismatic and cylindrical test specimens were produced, considering the various tests to be conducted with each type of concrete. The appropriate moulds were filled to obtain prismatic standard $40 \times 40 \times 160 \mathrm{~mm}$ specimens or (non-standard) cylinders of 100 $\mathrm{mm}$ diameter by $50 \mathrm{~mm}$ height. Mixing procedure described in Normas Portuguesas-NPEN 196-1 (1996) for cement mortar was generally followed with the following differences: the dry lightweight aggregate was mixed with a third of the total water at low speed for $2 \mathrm{~min}$ and then allowed to rest for a further $3 \mathrm{~min}$. The remaining materials were added including the superplasticizer which was dosed with a dropper and added to the remaining water to be added. Mixing procedure was continued for a further $3 \mathrm{~min}$ in relation to standard time. No compaction was carried out so moulds were filled immediately after assessing workability. After one day the specimens were demolded and then cured in accordance with the standard procedure, in water at $20^{\circ} \mathrm{C}$.

Workability: The measuring procedure is described in the American Society for Testing and Materials - ASTM 230M-03 (2003) and ASTM 1437-01 (2001). Control concrete workability was set as the target workability and superplasticizer was added so as to obtain the equivalent workability $( \pm 10 \mathrm{~mm})$ for all the three different types of concrete.

Strength and Activity Index: Concrete mechanical strength was determined at ages 3, 7, 28 and 90 days, following the standard procedure described in NP EN 1961 (1996). The $40 \times 40 \times 160 \mathrm{~mm}$ specimens of each concrete type were weighed for specific gravity determination and further tested in flexure and in compression. The Activity Index of a certain percentage of cement replacement by an addition corresponds to comparing strength of concrete produced with that percentage replacement with the strength of equivalent concrete without cement replacement, at the same age, in this case 28 and 90 days produced in exactly the same conditions.

Table 2 - Mixture proportions of concrete types.

\begin{tabular}{lccc}
\hline & Control (CTL) & 10\% RHA (RHA) & 10\% BBA (BBA) \\
\hline Cement (C) & 1.000 & 0.900 & 0.900 \\
Rice Husk Ash (RHA) & - & 0.100 & - \\
Broiler Bed Ash (BBA) & & - & 0.100 \\
Superplasticizer (SP) & 0.0079 & 0.022 & 0.022 \\
Lightweight aggregate (LWA) & 0.814 & 0.814 & 0.814 \\
Sand (S) & 1.389 & 1.389 & 1.389 \\
Effective water (W) & 0.380 & 0.380 & 0.380 \\
Absorbed water (0.07LWA) & 0.057 & 0.057 & 0.057 \\
Total water & 0.437 & 0.437 & 0.437 \\
\hline
\end{tabular}


Absorption by capillarity: Transport properties of the concrete surface, which play a major role in durability of reinforced concrete, are controlled by three mechanisms; namely, capillary absorption, permeability, and diffusion (NEVILLE, 1998). Usually, the more resistant concrete is to the ingress of aggressive agents (water or carried ions, oxygen, and carbon dioxide), the more durable it will be. In the present study water absorption by capillarity, chloride ion migration, resistivity, and accelerated carbonation tests were carried out to assess the material ageing.

To consider the ability of the concrete surface to absorb water by capillary action, the RILEM TC116-PCD (1999) recommendation was adopted as a basis. The molded side faces of $100 \mathrm{~mm}$ diameter and $50 \mathrm{~mm}$ height cylindrical specimens were tested, instead of the molded bottom face of $150 \mathrm{~mm}$ cube specimens used in the RILEM recommendation. The 63 (instead of 28) days old standardcured (water at $20^{\circ} \mathrm{C}$ ) specimens were allowed to dry in a ventilated heater at $40^{\circ} \mathrm{C}$ until constant mass was achieved.

After cooling to $20^{\circ} \mathrm{C}$, the specimens were put on rods in a shallow bath of water at $20^{\circ} \mathrm{C}$, approximately 3 $\mathrm{mm}$ deep. The uptake of water by capillary absorption was measured through the weight gain of each specimen at time intervals until $04 \mathrm{~h} 30$ of contact with water. The absorption of water into concrete under capillary action is dependent on the square-root of time and may be modeled by the following (Equation 1) (HALL, 1989):

$$
A=a_{0}+S t^{0.5}
$$

where, $A\left(\mathrm{mg} / \mathrm{mm}^{2}\right)$ is the water absorption by unit area since the time the specimen was dipped in the shallow bath; $S\left(\mathrm{mg} /\left(\mathrm{mm}^{2} \times \mathrm{min}^{0,5}\right)\right)$ is the "sorptivity" of the material; $t$ is the elapsed time in minutes and $a_{0}\left(\mathrm{mg} / \mathrm{mm}^{2}\right)$ is the water initially absorbed by pores in contact with water.

Chloride ion penetration: Chloride ion penetration was assessed by the Luping method, which is a non-steady state migration method based on a theoretical relation between diffusion and migration. This enables the calculation of the apparent chloride diffusion coefficient $\left(D_{n s}\right)$ from an accelerated test (NORDTEST METHODNT:BUILD-492, 1999; LABORATÓRIO NACIONAL DE ENGENHARIA CIVIL-LNEC:E-463, 2004). This method is based on measuring the depth of color change of a silver nitrate solution sprayed on the specimens previously submitted to a migration test. Specimens (100 mm diameter by $50 \mathrm{~mm}$ height) were submitted to an electrical current corresponding to a potential difference, in this case, of 30 $\mathrm{V}$, during 24h00. Chloride ions are forced to migrate out of a $\mathrm{NaCl}$ solution subjected to a negative charge at the surface of the specimen, through the concrete into a $\mathrm{NaOH}$ solution maintained at a positive potential at the opposite surface of the specimen. The specimens are then split open, sprayed with nitrate solution and the chloride penetration depth $\left(\mathrm{x}_{\mathrm{d}}\right)$ is measured so as to enable calculation of the apparent diffusion coefficient $\left(\mathrm{D}_{\mathrm{ns}}\right)$ (Equation 2).

$\mathrm{D} n s=\frac{0.0239(273+\mathrm{T}) \mathrm{L}}{(\mathrm{U}-2) \mathrm{t}}\left(x_{d}-0.0238 \sqrt{\frac{(273+T) L x_{d}}{U-2}}\right)$ (2)

where $\mathrm{D}_{\mathrm{ns}}$ is the non-steady-state migration coefficient $(\times 10$ $\left.{ }^{-12} \mathrm{~m}^{2} \mathrm{~s}^{-1}\right)$, $\mathrm{U}$ is the absolute value of the applied voltage (V), $\mathrm{T}$ is the average value of the initial and final temperatures in the anodic solution $\left({ }^{\circ} \mathrm{C}\right), \mathrm{L}$ is the thickness of the specimen, usually $50 \mathrm{~mm}, \mathrm{x}_{\mathrm{d}}$ is the average value of measured chloride penetration depth $(\mathrm{mm})$ and $t$ is the testing period $(\mathrm{h})$.

Resistivity: Concrete resistivity is another parameter that contributes to durability assessment. When pores are saturated, the electric current flow is more easily dependant on the pore structure. Prior to the chloride migration test described above, specimens are presaturated. Therefore, when current is imposed during the test it is possible to evaluate resistivity (Equation 3) in saturated conditions to compare different types of concrete.

$\rho \equiv R \cdot \frac{A}{L} \equiv \frac{V \cdot A}{L \cdot I}$

where $\mathrm{R}$ is the electric resistance, $(\Omega-\mathrm{Ohm})$; I, current (A); V, voltage (V); r, electric resistivity ( $\Omega . \mathrm{m})$; L, length (m); and $\mathrm{A}\left(\mathrm{m}^{2}\right)$, the area of the test specimen across which current passes.

Carbonation: Accelerated carbonation tests were carried out following the procedure described in LNEC E391 (2004), and using a chamber with 5\% carbon dioxide and relative humidity $(\mathrm{RH})$ of approximately $65 \%$.

Test specimens measuring $40 \times 40 \times 160 \mathrm{~mm}$ of each concrete type were kept in the chamber for two months, after three months of curing in water at $20^{\circ} \mathrm{C}$. A slice from each test specimen was sawed off and sprayed with phenolphthalein solution, enabling the measurement of the carbonation depths. 


\section{RESULTSAND DISCUSSION}

Rice husk ash: Chemical analysis, carried out by X-Ray Fluorescence is shown in table 3 and compared to values presented by Umamaheswaran and Batra (2008). Presenting the laser particle-size distribution shown in figure 2, the X Ray diffraction pattern confirming mainly amorphous material, shown in figure 3 and the BET surface area of $67.5 \mathrm{~m}^{2} \mathrm{~g}^{-1}$. SEM images in figure 4 , show angular particles containing $\mathrm{Si}$ and $\mathrm{Ca}$.

Broiler bed ash: Chemical analysis, carried out by $\mathrm{X}$-Ray Fluorescence is shown in table 3. Presenting the laser particle size distribution shown in figure 5, the X Ray diffraction pattern displaying the presence of crystalline material in figure 6 and the BET surface area of $7.0 \mathrm{~m}^{2} \mathrm{~g}^{-1}$.
SEM images in figure 7 show a more complex chemical composition with particles containing main elements such as $\mathrm{P}, \mathrm{K}, \mathrm{Ca}, \mathrm{Mg}, \mathrm{Cl}$ and $\mathrm{Ca}$.

Mechanical and fast ageing related results are shown in table 4.

Results concerning BBA concrete compared to control, show that compressive strength although slightly lower for early ages, tends to increase with age achieving similar levels at 90 days. In terms of degradation analyzed through sorptivity, $\mathrm{D}_{\mathrm{ns}}$, resistivity and carbonation, BBA deeply reduced performance of concrete compared to control concrete most probably because of inadequate chemical composition, especially the excess of carbon content presumably corresponding to the high LOI of the ash (approximately 12\%).

Table 3 - Chemical analysis by X-Ray Fluorescence for RHA, BBA and results for RHA by other authors (METHA, 1994; UMAMAHESWARAN; BATRA, 2008).

\begin{tabular}{cccc}
\hline & Rice Husk Ash (\%) & Broiler Bed Ash (\%) & RHA(\%) (UMAMAHESWARAN; BATRA, 2008) \\
\hline $\mathrm{SiO}_{2}$ & 91.80 & 37.70 & 93.52 \\
$\mathrm{Al}_{2} \mathrm{O}_{3}$ & 0.06 & 1.30 & 0.01 \\
$\mathrm{Fe}_{2} \mathrm{O}_{3}$ & 0.09 & 0.67 & 0.51 \\
$\mathrm{CaO}$ & 1.02 & 15.40 & 0.68 \\
$\mathrm{Na}_{2} \mathrm{O}$ & 0.06 & 2.79 & 0.40 \\
$\mathrm{~K}_{2} \mathrm{O}$ & 1.73 & 6.64 & 2.40 \\
$\mathrm{MnO}$ & 0.31 & 0.16 & 0.47 \\
$\mathrm{TiO}_{2}$ & - & 0.06 & 0.04 \\
$\mathrm{MgO}$ & 0.42 & 4.23 & \\
$\mathrm{P}_{2} \mathrm{O}_{5}$ & 0.94 & 13.90 & 1.06 \\
$\mathrm{SrO}$ & 0.01 & 0.11 & \\
Loss on Ignition & 2.86 & 11.70 & 0.80 \\
\hline
\end{tabular}

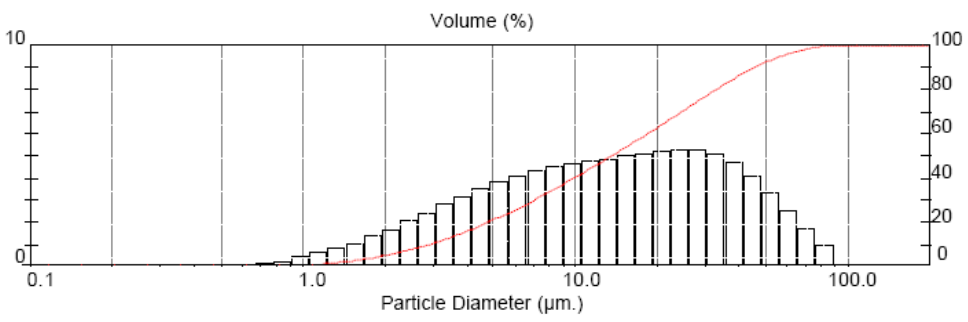

Figure 2 - RHA laser particle-size distribution. 


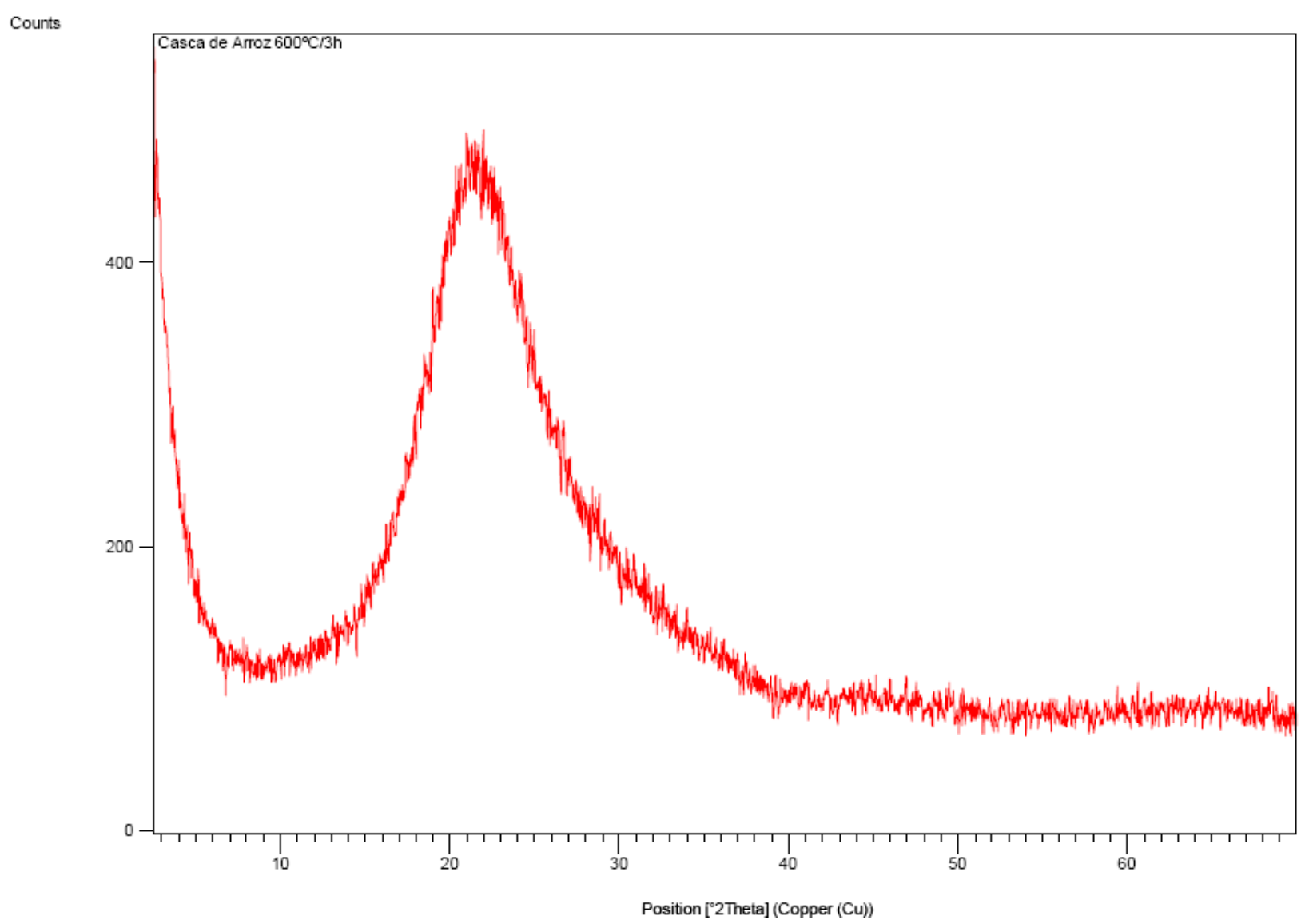

Figure 3 - X Ray diffraction pattern of RHA showing mainly amorphous material.

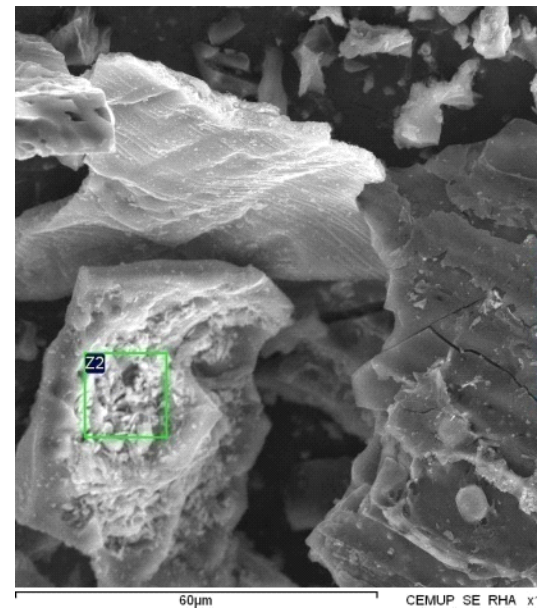

SEM image of RHA particles, X 1000

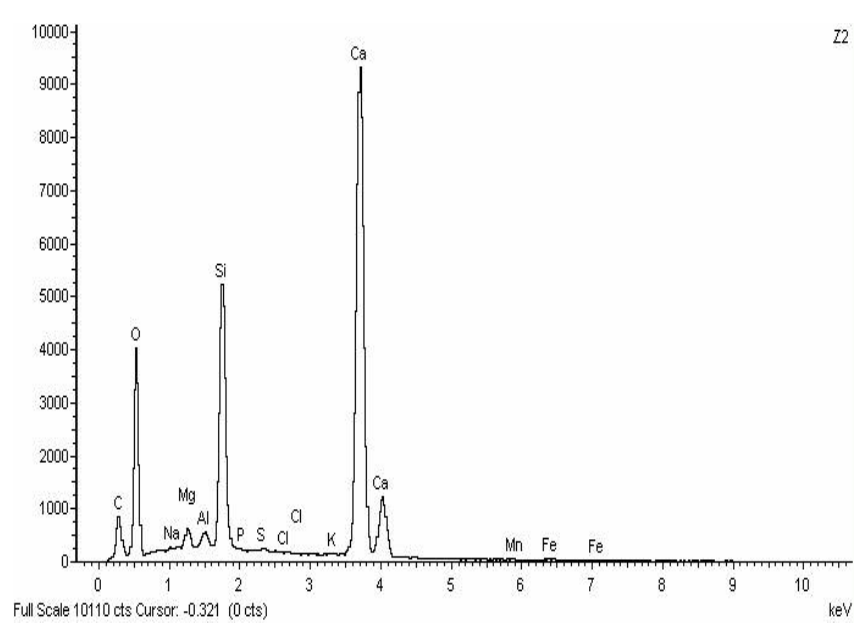

Spectrum of zone Z2

Figure 4 - SEM study of the particles morphology and elementary spectrum for the RHA.

Ciênc. agrotec., Lavras, v. 36, n. 5, p. 567-578, set./out., 2012 


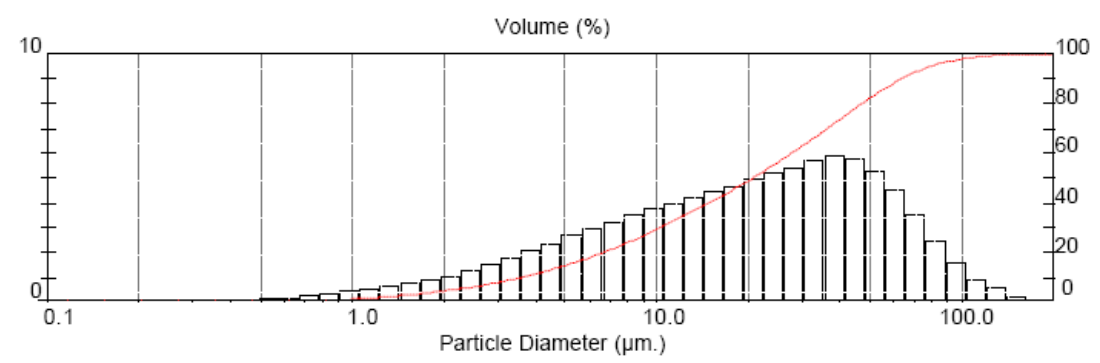

Figure 5-BBA laser particle-size distribution.

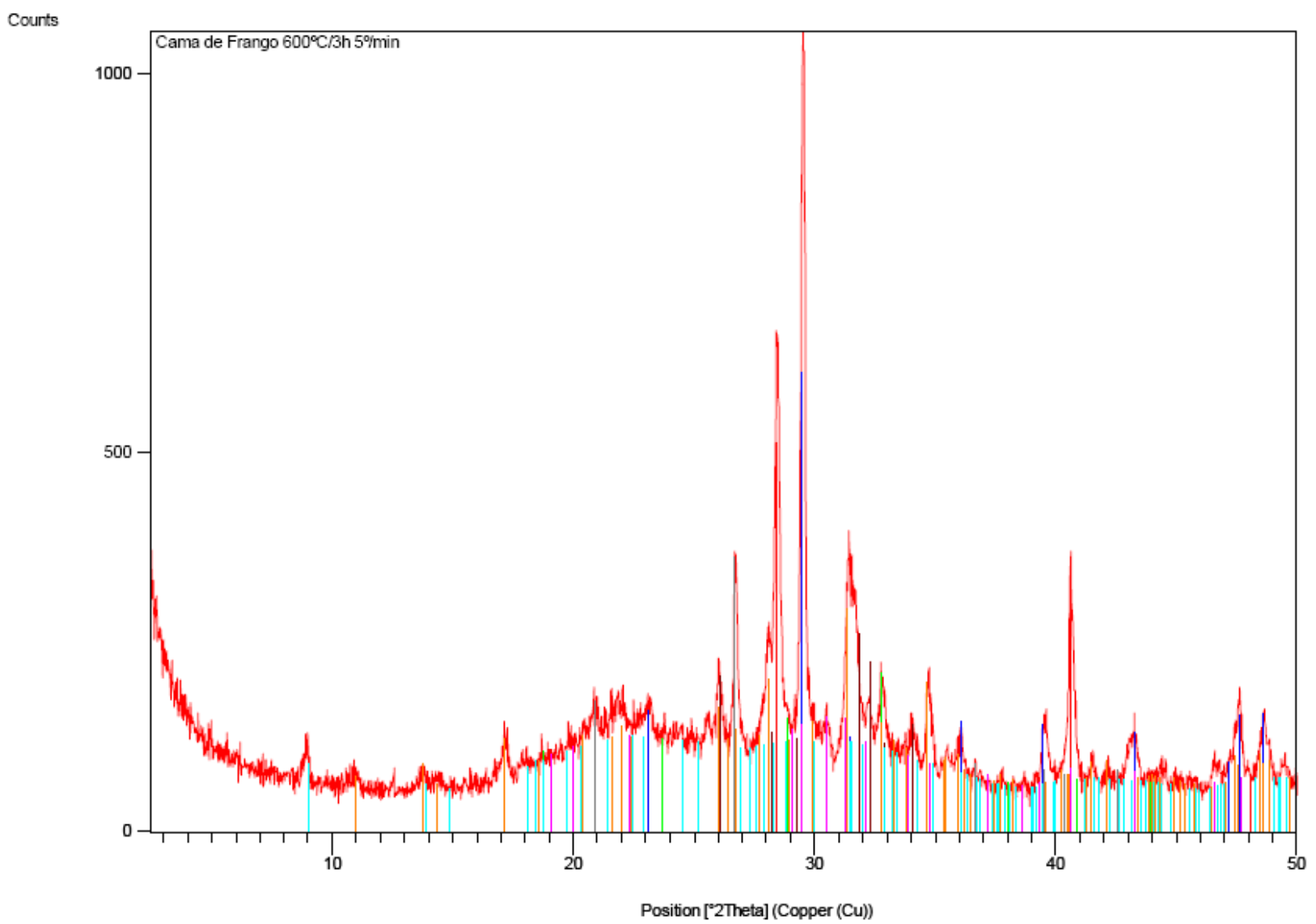

Figure 6-X Ray diffraction pattern of BBA displaying the presence of crystalline material.

RHA results show that strength is higher than equivalent values for CTL concrete confirming observations byZhang and Malhotra (1996) for normal weight concrete. In particular Neville (1998) observed that rice husk ash is reported to contribute to strength of concrete already at 1 to 3 days of age. Such a behavior can be understood by the refinement of the pore structure with the consequent reduction of permeability and increase in mechanical strength of the cement based material as reported by Rodrigues, Ghavami and Stroeven, (2006) and Cordeiroet al. (2012).

In terms of degradation, sorptivity values for RHA were similar to CTL concrete contradicting observations by other authors for normal weight concrete. The estimates for two month old concrete from observations by Ganesan,

Ciênc. agrotec., Lavras, v. 36, n. 5, p. 567-578, set./out., 2012 
Rajagopal and Thangavel et al. (2008) led to reduction of sorptivity from $0.081 \mathrm{mg} /\left(\mathrm{mm}^{2} \times \mathrm{min}^{0.5}\right)$ for control concrete with water/binder ratio of 0.53 and 28 day compressive strength of $37.1 \mathrm{MPa}$ to $0.054 \mathrm{mg} /\left(\mathrm{mm}^{2} \times \mathrm{min}^{0.5}\right)$ for concrete with $10 \%$ RHA. Both chemical and physical properties of the pozzolanic ash can determine the different behavior obtained in the referred study conducted by Ganesan, Rajagopal and Thangavel . (2008) furthermore if considering that this material constitutes an agriculture waste.

Testing each specimen led to average sorptivity results (Figure 8 and table 4 ) and correlation coefficients (R) over 0.987 .

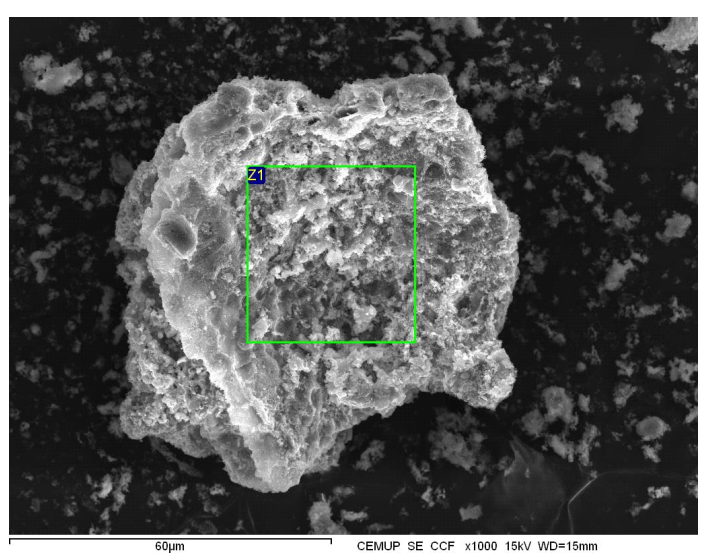

SEM image of BBA particles, X 1000

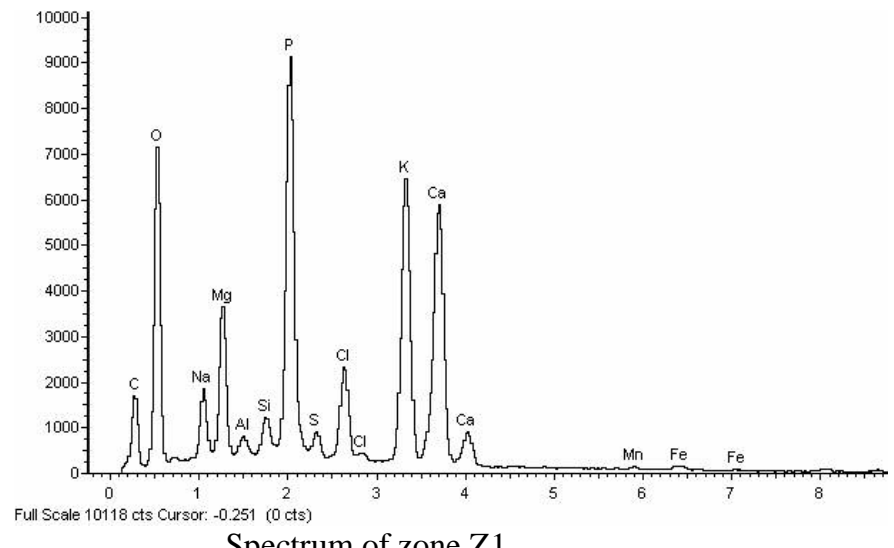

Spectrum of zone $\mathrm{Z1}$

Figure 7 - SEM study of the particles morphology and elementary spectrum for the BBA.

Table 4 - Mechanical and fast ageing related results on lightweight concrete (value \pm standard deviation).

\begin{tabular}{|c|c|c|c|c|}
\hline Property ( $\mathrm{n}=$ number of test specimens) & & CTL & RHA & BBA \\
\hline Flow diameter $(n=6)$ & $\mathrm{mm}$ & $200.8 \pm 0.8$ & $191.2 \pm 0.3$ & $194.5 \pm 0.6$ \\
\hline Specific gravity, $90 \mathrm{~d}(\mathrm{n}=3)$ & $\mathrm{kg} / \mathrm{m}^{3}$ & $1879 \pm 3$ & $1851 \pm 3$ & $1902 \pm 3$ \\
\hline Flexural strength, $3 d \quad(n=3)$ & $\mathrm{MPa}$ & $6.1 \pm 0.0$ & $6.5 \pm 0.1$ & $5.9 \pm 0.2$ \\
\hline Flexural strength, $7 d(n=3)$ & $\mathrm{MPa}$ & $6.4 \pm 0.3$ & $7.1 \pm 0.3$ & $6.1 \pm 0.2$ \\
\hline Flexural strength, $28 \mathrm{~d}(\mathrm{n}=3)$ & $\mathrm{MPa}$ & $7.2 \pm 0.4$ & $8.2 \pm 0.9$ & $6.3 \pm 0.2$ \\
\hline Flexural strength, $90 \mathrm{~d}(\mathrm{n}=3)$ & $\mathrm{MPa}$ & $7.1 \pm 0.6$ & $7.1 \pm 0.3$ & $6.1 \pm 0.1$ \\
\hline Compressive strength, $3 \mathrm{~d}(\mathrm{n}=4)$ & $\mathrm{MPa}$ & $39.2 \pm 1.8$ & $43.1 \pm 2.3$ & $37.3 \pm 1.4$ \\
\hline Compressive strength, $7 d(n=6)$ & $\mathrm{MPa}$ & $42.4 \pm 1.5$ & $46.7 \pm 1.3$ & $38.0 \pm 1.6$ \\
\hline Compressive strength, $28 \mathrm{~d}(\mathrm{n}=6)$ & $\mathrm{MPa}$ & $49.1 \pm 2.6$ & $50.7 \pm 3.5$ & $46.1 \pm 3.9$ \\
\hline Compressive strength, $90 \mathrm{~d}(\mathrm{n}=6)$ & $\mathrm{MPa}$ & $49.8 \pm 3.2$ & $52.3 \pm 3.3$ & $50.6 \pm 3.1$ \\
\hline Activity Index, 28d $(\mathrm{n}=6)$ & $\%$ & & 103 & 94 \\
\hline Activity Index, 90d $(n=6)$ & $\%$ & & 105 & 102 \\
\hline Sorptivity, 63d $(\mathrm{n}=3)$ & $\mathrm{mg} /\left(\mathrm{mm}^{2} \times \min ^{0.5}\right)$ & $0.065 \pm 0.003$ & $0.066 \pm 0.000$ & $0.119 \pm 0.004$ \\
\hline Quality class (sorptivity) & & high & high & medium \\
\hline $\mathrm{D}_{\mathrm{ns}}, 63 \mathrm{~d}(\mathrm{n}=3)$ & $\times 10^{-12} \mathrm{~m}^{2} / \mathrm{s}$ & $8.8 \pm 0.3$ & $4.3 \pm 0.1$ & $13.2 \pm 0.7$ \\
\hline Chloride resistance class & & high & very high & moderate \\
\hline Resistivity, 63d (n=3) & $\Omega . \mathrm{m}$ & $84.9 \pm 0.8$ & $147.9 \pm 0.3$ & $45.5 \pm 2.0$ \\
\hline Carbonation $(\mathrm{n}=1)$ & $\mathrm{mm}$ & 5 & 0 & 6 \\
\hline
\end{tabular}

Ciênc. agrotec., Lavras, v. 36, n. 5, p. 567-578, set./out., 2012 


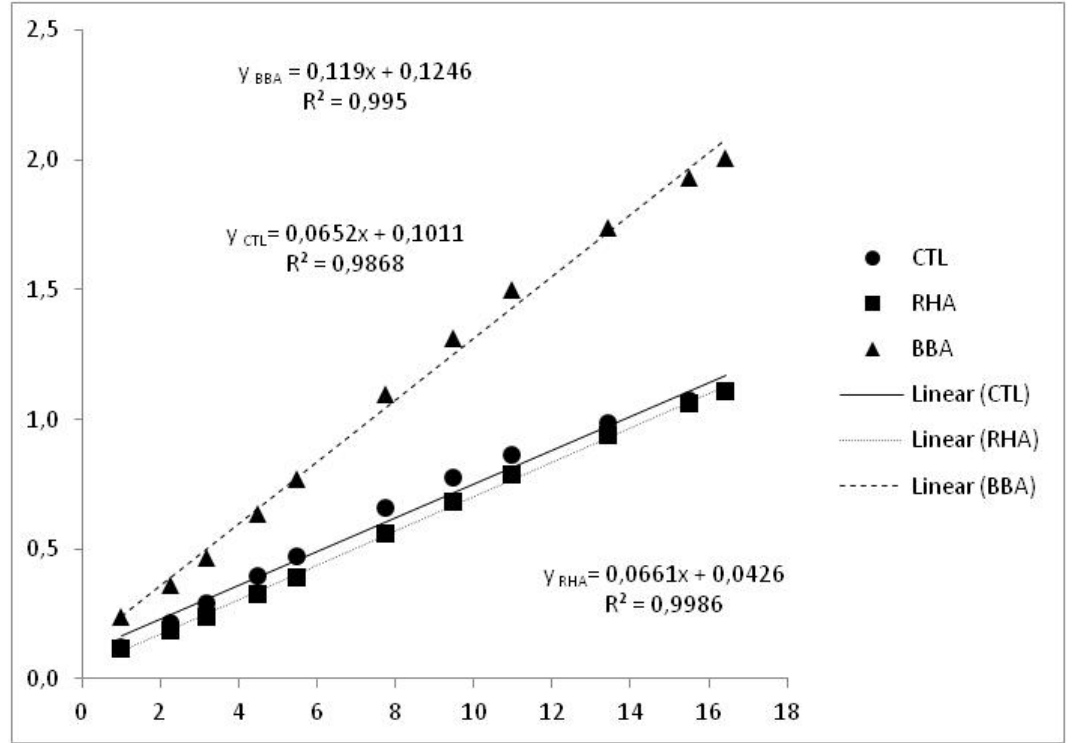

Figure 8 - Capillary absorption for the first $04 \mathrm{~h} 30$ comparing the three different types of lightweight concretes (CTL, RHA and BBA).

Sorptivity obtained in the present study for CTL lightweight concrete, with water/binder ratio of 0.38 , was of $0.065 \mathrm{mg} /\left(\mathrm{mm}^{2} \times \mathrm{min}^{0.5}\right)$, and seems to agree with the equivalent values by Ganesan, Rajagopal and Thangavel (2008) although for normal weight concrete. In terms of sorptivity for RHA concrete Ganesan, Rajagopal and Thangavel (2008) used much finer RHA with a mean particle size distribution of $3.8 \mu \mathrm{m}$ compared to $53 \mu \mathrm{m}$ used in the present study, that may explain the non enhancement of sorptivity results by RHA.

Resistance to chloride ion penetration in lightweight concrete improved $51 \%$ with RHA replacement, considering the diffusion coefficients $\mathrm{D}_{\mathrm{ns}}$. This confirms observations by other authors who, using different setups, reported the improvement in resistance to chloride ion penetration in RHA normal weight concrete compared to CTL, of around:

- $66 \%$ reduction of Coulombs passed for the Rapid Chloride Permeability Test (RCPT) according to ASTMC1202 (1997) estimated for two month old RHA and CTL concrete types from values presented by Ramasamy e Biswas (2008) where control concrete with water/binder ratio of 0.43 and 28 day compressive strength of $44 \mathrm{MPa}$.

- $60 \%$ reduction of Coulombs passed for the Rapid Chloride Permeability Test (RCPT) according to C1202 (1997) with 28 day old RHA and CTL concrete types where control concrete with water/binder ratio of 0.45 and 28 day strength of $42 \mathrm{MPa}$ (SALAS et al., 2009).
Resistivity with RHA replacement improved from $85 \Omega . m$ in CTL concrete to $148 \Omega$.m at two months. These results are in accordance with observations by Salas et al. (2009), where CTL normal weight concrete with water/binder ratio of 0.40 and 28 day strength of $52 \mathrm{MPa}, 28$ day resistivity

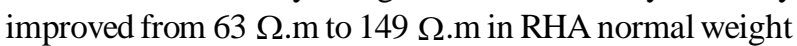
concrete. Carbonation with RHA replacement also reduced substantially what is a desirable result in those situations where the protection of the reinforcing steel against corrosion is a key issue. This is also the case for agriculture applications of concrete based structures under aggressive environmental conditions as pointed out by Moradian et al. (2012).

\section{CONCLUSIONS}

BBA is considered less appropriate for cement replacement in lightweight aggregate concrete in regard to fast ageing tests, most probably due to chemical properties. This can be associated to the lower silica content and higher LOI compared to RHA, and also the relatively high contents of potentially adverse oxides such as $\mathrm{Na}_{2} \mathrm{O}(3 \%)$ and $\mathrm{P}_{2} \mathrm{O}_{5}(14 \%)$. Nevertheless, mechanical results concerning BBA lightweight aggregate concrete compared to control, show that compressive strength increased with age, achieving similar levels at 90 days. That enhancement on mechanical behavior can be indicative for potential interest in applications of plain concrete (without steel 
reinforcement) and where the concrete is maintained apart from degradation agents such those under consideration in the present study.

Usually other pozzolanic materials, including silica fume, lead to a slower strength development at early ages but RHA provided strength increase in the present study. RHA contributed to the enhancement of most properties related to fast ageing related tests specially for carbonation resistance and also in terms of chloride ion penetration.

Present results show that replacement with $10 \%$ RHA leads to improvement in strength and durability related properties of control lightweight aggregate concrete, an insulating material which reduces energy consumption in buildings. The use of RHA, a raw material which derives from agroindustrial waste, therefore further contributes to sustainability in construction by reducing the clinker consumption in lightweight concrete without impairment of the general performance of the final product.

\section{AKNOWLEDGEMENTS}

The authors would like to thank Maxit and SECIL for materials and information. The two Brazilian authors are also in debt with Brazilian funding agencies Fapesp (process n. 03/10123-0) and CNPq (process n. 305792/ 2009-1) for their financial support.

We are grateful to the anonymous referees for their helpful comments and suggestions. This work was financed in Portugal, by FEDER funds under the Operational Program Factors of Competiveness COMPETE and by National Funds under FCT Foundation for Science and Technology through project PTDC/ECM/098117/2008 Additions from waste materials for sustainable structural concrete.

\section{REFERENCES}

\section{AMERICAN SOCIETY FOR TESTING AND}

MATERIALS - ASTM - C1202: Standard test method for electrical indication of concrete's ability to resist chloride ion penetration. West Conshohocken, PA, 1997.6p.

\section{AMERICAN SOCIETYFOR TESTINGAND} MATERIALS - ASTM - C230/C230M: Standard Specification for Flow Table for Use in Tests of Hydraulic Cement. West Conshohocken, PA, 2003. 7p.

\section{AMERICAN SOCIETYFOR TESTINGAND} MATERIALS - ASTM - C1437-01: Standard Test Method for Flow of Hydraulic Cement Mortar. West Conshohocken, PA, 2001. 2p.
BOUZOUBAÂ, N.; FOURNIER, B. Concrete incorporating Rice-Husk Ash: Compressive strength and chloride-ion penetrability.. Materials Technology Laboratory. International Centre for Sustainable Development of Cement and Concrete (ICON), CANMET, Natural Resources Canada, Ottawa, Jul., 2001

CHANDRA, S.; CHAO, L.H. The use of rice husk in concrete. Waste materials used in concrete manufacturing. W. Andrew, Noyes publications. United States, 1997.

CHAO-LUNG, H.; ANH-TUAN, B.; CHUN-TSUN, C. Effect of rice husk ash on the strength and durability characteristics of concrete. Construction and Building Materials, Oxford, v.25, n.9, p.3768-3772, September. 2011.

CHINDAPRASIRT, P.; RUKZON, S. Strength, porosity and corrosion resistance of ternary blends Portland cement, rice husk ash and fly ash mortar. Construction and Building Materials, Oxford, v.22, n.8, p.1601-1606, August. 2008.

CORDEIRO, G.C. et al. Experimental characterization of binary ad ternary blended-cement concretes containing ultrafine residual rice husk and sugar cane bagasse ashes. Construction and Building Materials, Oxford, v.29, p.641-646, April, 2012.

FAIRBAIRN, E.M.R. et al. Cement replacement by sucar cane bagasse ash: $\mathrm{CO}_{2}$ emissions reduction and potential for carbon credits. Journal of Environmental Management, London, v.91, n.9, p.1864-1871, September, 2010.

GANESAN, K.; RAJAGOPAL, K.; THANGAVEL, K. Evaluation of bagasse ash as supplementary cementitious material. Cement \& Concrete Composites, Oxford, v.29, n.6, p.515-524, July. 2007.

GANESAN, K.; RAJAGOPAL, K.; THANGAVEL, K. Rice hush ash blended cement: Assessment of optimal level of replacement for strength and permeability properties of concrete. Construction and Building Materials, Oxford, v.22, n.8, p.1675-1683, August. 2008.

HALL, C. Water sorptivity of mortars and concrete: a review. Magazine of Concrete Research, London, v.41, n.147, p.51-61, Jun. 1989. 
LABORATÓRIO NACIONALDE ENGENHARIACIVIL - LNEC. LNEC: E-391: Determinação das resistências à carbonatação. Lisboa, 1993.

\section{LABORATÓRIONACIONALDE ENGENHARIACIVIL} - LNEC. LNEC: E-463: Determinação do coeficiente de difusão dos cloretos por ensaio de migração em regime não estacionário. Lisboa, 2004.

MORADIAN, M. et al. Deterioration of concrete caused by complex attack in sewage treatment plant environment - case study. Journal of Performance of Constructed Facilities, Reston, v.26, n.1, p.124-134, Jan-Feb, 2012.

NEVILLE, A.M. Properties of Concrete. Longman Publishers, Essex 1998, p. 241-291.

NORMA PORTUGUESA - NP. NPEN 196-1: Métodos de ensaio de cimentos. Parte 1: Determinação das resistências mecânicas. Instituto Português da Qualidade, Monte de Caparica. 1996. 26p.

NORMA PORTUGUESA - NP. NPEN 197-1: CimentoParte 1: Composição, especificações e critérios de conformidade para cimentos correntes. Instituto Português da Qualidade, Monte de Caparica. 2001. 35p.

NORDTEST METHOD. NT:BUILD-492: Concrete, mortar and cement-based materials: chloride migration coefficient from non-steady-state migration experiments. Oslo, 1999. 8p.

RAMASAMY, V.; BISWAS, S. Mechanical properties and durability of rice husk ash concrete. International Journal of Applied Engineering Research, Delhi, v.3, n.12, p.1799-1811, Dec. 2008.

RILEM TC116-PCD. RILEM TC116-PCD: Permeability of Concrete as a Criterion of its Durability. Final Report. Concrete durability: an approach towards performance testing. Materials and Structures, Dordrecht, v.32, n.217, p.163-173, Apr. 1999.

RODRIGUES, C.S.; GHAVAMI, K.; STROEVEN, P. Porosity and wáter permeability of rice husk ash-blended cement composites reinforced with bamboo pulp. Journal of Materials Science, New York, v.41, n.21, p.6925-6937, Nov., 2006.

SAFIUDDIN, M.; WEST, J.; SOUDKI, K. Properties of freshly mixed self-consolidating concretes incorporating rice husk ash as a supplementary cementing material. Construction and Building Materials, Oxford, v.30, n.1, p. 833-842, May. 2012

SALAS, A. et al. Comparison of two processes for treating rice husk ash for use in high performance concrete. Cement and Concrete Research, Oxford, v.39, n.9, p.773-778, Sep. 2009.

SWAMY, R. N. Sustainable Concrete for the 21st Century: Concept of Strength through Durability. Japan Society of civil engineers in Concrete Committee Newsletter, White Rose Research Online, v.13, 2008. Disponível em: < http://eprints. whiterose.ac.uk/4617/ >. Acesso em: 22 de feb. 2012.

UMAMAHESWARAN, K.; BATRA, V.S. Physicochemical characterisation of Indian biomass ashes. Fuel, Oxford,v.87, n.6, p.628-638, May. 2008.

ZAIN, M.F.M. et al. Production of rice husk ash for use in concrete as a supplementary cementitious material. Construction and Building Materials, Oxford, v.25, n.2, p.798-805, Feb. 2011

ZHANG, M.H.; MALHOTRA, V.M. High-performance concrete incorporating rice husk ash as a supplementary cementing material. Materials Journal, Farmington Hills, v.93, n.6, p. 629-636, Nov. 1996. 